\title{
Hurricane link to climate change is hazy
}

Will destructive hurricanes such as Katrina become more common in a warmer world? Two recent studies suggest that they will. But the question has split the research community (see Nature 435, 1008-1009; 2005), and some say that the studies highlight how little is known about the physics of hurricane formation.

The media, and some politicians, have been quick to blame global warming for the disastrous Atlantic hurricane seasons of 2004 and 2005 , induding Katrina. The two new studies make no such direct link, but do suggest that the intensity - although not the frequency of tropical cyclones is increasing sharply, perhaps as a result of global warming.

The first study, published in August (Nature $436,686-688 ; 2005$ ), shows that cyclones have become more destructive over the past 30 years, with storms being both longer lived and more intense. The second, published last week (Science 309, 1844-1846; 2005), concludes that today's cyclones are stronger, although less common, than 35 years ago.

${ }^{\alpha}$ The potential for more events like Katrina is on the rise," says Greg Holland, a hurricane expert at the National Center for Atmospheric Research in Boulder, Colorado, and an author of the Science paper. "You can never be sure, but it seems to be consistent with global change."

But not everyone is convinced. "Hurricanes tend to go in decadal cycles," points out Chris

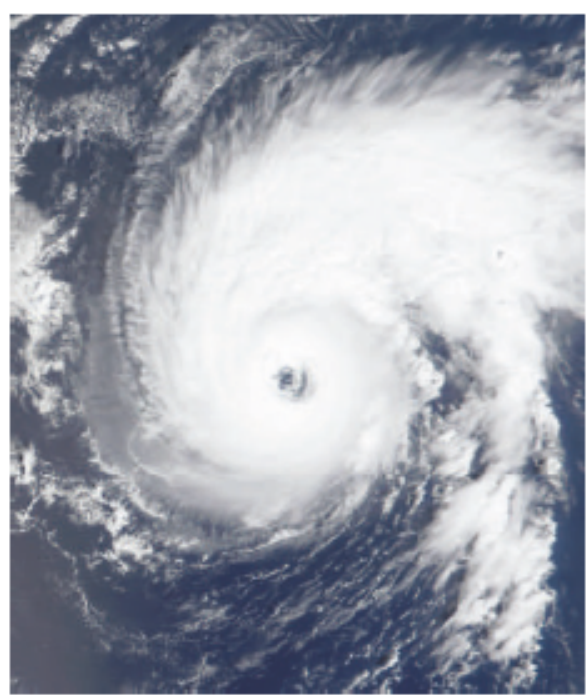

A brace of studies indicates that cyclones have increased in strengthover the past 30 years.

Landsea, a meteorologist at the US National Hurricane Center in Miami, Florida. "Making out the tiny global-warming signal amid these large natural swings is hardly possible at this point."

And although the new studies are persuasive, they are not definitive. For instance, the Science paper concludes that peak wind speeds have remained constant since 1970 . But this finding seems to be inconsistent with the trend towards stronger storms, says Kerry
Emanuel, a researcher at the Massachusetts Institute of Technology and author of the Nature paper.

Many of the arguments arise because there are insufficient data. ${ }^{\alpha}$ There seems to be a monumental lack of understanding of the role hurricanes play in the climate system," says Peter Webster, an atmospheric researcher at the Georgia Institute of Technology in Atlanta and an author of the Science paper.

One uncertainty, he says, is how changes in sea surface temperature affect the formation of tropical cyclones. Hurricanes in the Atlantic Ocean, for example, seem to respond to such changes quite differently from typhoons in the Pacific. But just $12 \%$ of cyclones form in the Atlantic, the only region where reconnaissance aircraft fly regularly to make precise measurements of hurricane winds.

Research is now under way to address the issue. As a follow-up to the Science paper, the authors have started to investigate how oceans interact with the atmosphere in different parts of the world. The goal, says Judy Curry of the Georgia Institute of Technology, is to determine how and why natural fluctuations favour different hurricane patterns in different ocean basins.

Understanding these complex mechanisms, she says, should help researchers better quantify how much a storm trend is due to global warming - or not.

Quirin Schiermeier

\section{Lack of lab notes casts doubt on RNA researcher's results}

\section{TOKYO}

A respected Japanese scientist who failed to produce laboratory notebooks confirming his published results now faces a furore over the credibility of his findings.

On 13 September, the University of Tokyo's School of Engineering held a press conference to say that Kazunari Taira, a professor at the school who specializes in RNA research, had not provided rawdata to verify his team's results. The RNA Society of Japan has also questioned some of Taira's methods.

Last year, the RNA Society of Japan began receiving letters from scientists in Japan and elsewhere saying that they could not repeat Taira's results. In April the society asked the University of Tokyo to examine 12 of Taira's papers published between 1998 and 2004.

The university set up a committee of internal and external experts to examine four papers out of the 12, including two published in Nature (H. Kawasaki and K. Taira Nature 423, 838-842; 2003 and Nature 431, 211-217; 2004) - the first paper had already been retracted (Nature 426,100 ; 2003) and the second corrected (Nature 431, $878 ; 2004)$. The panel asked Taira to submit samples and notebooks relating to the experiments, but the researcher in his lab who ran the experiments did not have them. The researcher had stored data in a computer, some of which had since been scrapped.

The university press release said that "the investigation committee so far could not confirm the credibility of research results because it could not confirm the existence of clear data to support those results". It has asked Taira to do the experiments again, and will produce a final report by March 2006.

Taira says that not taking notes was "not common sense" and was regrettable. All the other researchers working with him keep notes, he says.

But Taira says that the oversight does not mean his methods are wrong, and says other groups have used his technique to publish findings. He also says that other researchers' notebooks back up some of the experiments. He now requires his researchers and students to get their notes signed by a third party.

Kimihiko Hirao, head of the School of Engineering, says that, unlike many countries, Japan doesn't have independent bodies to monitor scientific wrongdoing. "It's time to consider establishing a third-party regulatory system," he says. Ichiko Fuyuno 